\title{
IMPLEMENTASI TAHUN INFRASTRUKTUR DI PROVINSI JAWA TENGAH
}

\author{
Suwanto Adhi
}

\begin{abstract}
Year of infrastructure is the Central Java Provincial Government's policy since 2014 which is expected to improve the condition of infrastructure, particularly roads. Through qualitative method, this research focused on the meaning of infrastructure year and its impact.

The result showed that the year of the infrastructure is the policy of increasing budget allocations for rehabilitation and construction of roads through budget of Central Java. The result of the policy is better roads conditions. The success of the infrastructure year was supported by the commitment of parliaments in budgeting process and ability of local governments to implement all activities.
\end{abstract}

Keywords : Policy, Implementation, Infrastructure

\section{A. PENDAHULUAN}

Infrastruktur merupakan salah satu urusan penting dalam penyelenggaraan pemerintahan daerah. Melihat pentingnya pembangunan infrasrtuktur maka UndangUndang No 23 Tahun 2014 tentang Pemerintahan Daerah menempatkan urusan pekerjaan umum sebagai satu diantara enam urusan wajib yang berkaitan langsung dengan pelayanan dasar yang harus diselenggarakan oleh Pemerintah Daerah. Pemerintah Daerah diharapkan mampu melakukan pembangunan infrasrtuktur dengan baik sehingga akan berdampak pada kesejahteraan masyarakat di daerah maupun mendukung pembangunan nasional secara lebih luas.

Infrastruktur menjadi salah satu persoalan yang hingga kini masih menjadi salah satu penghambat kemajuan Provinsi Jawa Tengah. Fakta tersebut nampak dalam statistik ditahun 2012 dimana 7,184 km jalan dalam kondisi rusak, 347,385 km dalam kondisi sedang dari total panjang jalan yang menjadi kewenangan Pemerintah Provinsi sepanjang 2.565,621 km; 240,683 m jembatan dalam kondisi rusak, 5.251,946 m dalam kondisi sedang dari total panjang jembatan $25.335 \mathrm{~m}$ pada tahun 2012. Demikian halnya dengan cakupan air bersih yang baru mencapai 40,60\% untuk kawasan perkotaan dan 20,30\% untuk kawasan perdesaan. Apalagi jika dibandingkan dengan Provinsi Jawa Timur, DIY, dan Jawa Barat maka kondisi infrastruktur di Jawa Tengah nampak tertinggal.

Statistik tersebut tentu masih sangat debatel melihat kondisi yang dirasakan oleh masyarakat dan potensi bias dengan fakta yang ada di lapangan yang muncul akibat aspek kewenangan, metode maupun standarisasi perhitungan. Namun demikian satu hal yang pasti adalah bahwa infrastruktur di Jawa Tengah adalah persoalan yang harus segera diselesaikan melalui strategi yang efektif dan efisien.

Dalam perspektif perencanaan kebijakan, persoalan tersebut nampaknya telah mampu ditangkap dengan baik oleh Gubernur Jawa Tengah yang menjadikan infrastruktur sebagai isu strategis ketiga setelah kemiskinan, pengangguran dalam draf rencana pembangunan jangka menengah daerah (RPJMD) 2013-2018. Pembangunan infrastruktur juga telah menjadi salah satu program ungulan dari 11 program unggulan yang ditungakan dalam draf tersebut. Terlebih ketika pada tahun 2014 gubernur telah 
menetapkan sebagai tahun infrastruktur. Tahun infrastruktur sebagai program Pemerintah Provinsi yang diharapkan akan meningkatkan kualitas infrastruktur di Jawa Tengah.

Tahun infrastruktur disertai dengan peningkatan belanja untuk program dan kegiatan terkait infrastruktur. Peningkatan belanja infrastruktur pada tahun 2014 telah membawa peningkatan terhadap rasio belanja modal Jawa Tengah menjadi $10 \%$. Namun demikian dari peringkat secara nasional, peningkatan tersebut belum mampu menaikkan peringkat secara mkasimal. jika pada tahun 2013 Jawa Tengah menempati peringkat terrendah secara nasional, di tahun 2014 rasio belanja modal Jawa Tengah menempati peringkat keempat terkecil dan masih berada di bawah rata-rata nasional sebesar 19,56\%. Pada tahun 2014 alokasi anggaran untuk Program Peningkatan Jalan dan Penggantian Jembatan sebesar Rp 534, 55 milliar dan untuk Program Rehabilitasi/Pemeliharaan Jalan dan Jembatan Rp 310, 33 milliar.

Peningkatan alokasi anggaran dalam rangka mendukung tahun infrastruktur masih terus dilakukan pada tahun 2015. Jika pada tahun 2014 akumulasi dari anggaran infrastruktur mencapai Rp 1,255 triliun maka pada tahun 2015 jumlahnya mencapai Rp 2,572 trilyun dengan kata lain meningkatan lebih dari 100\%.

Selain peningkatan alokasi anggaran untuk pembangunan infrastruktur apa sebenarnya kebijakan yang menyertai tahun infrastruktur tersebut. Apakah kemudian tahun infrastruktur berdampak pada kemajuan pembangunan infrasrtuktur di Jawa Tengah dan bagaimana dampaknya terhadap bidang-bidang lainnya yang kemudian memperoleh porsi anggaran yang lebih sedikit.Demikian halanya bagaimana dengan dampak tahun infrastruktur terhadap pembangunan infrastruktur di Jawa Tengah apakah kemudian mampu meningkatkan kondisi infrastruktur di Jawa Tengah.

Penelitian ini akan menjawab lima pertanyaan yakni : “Apakah makna dari tahun infrastruktur yang dicanangkan oleh Gubernur Jawa Tengah Tahun 2014?, Aapakah bentuk kebijakan dari tahun infrastruktur di Provinsi Jawa Tengah?, Bagaimana pelaksanaan dari tahun infrastruktur di Provinsi Jawa Tengah?, Bagaimana dampak peningkatan alokasi anggaran untuk infrastruktur terhadap alokasi anggaran untuk bidang-bidang strategis lainnya? Dan bagaimana dampak dari tahun infrastruktur terhadap kondisi infrastruktur di Provinsi Jawa Tengah?".

Melalui pendekatan kualitatif sebagai unsur utama yang bersifat deskriptif analitis serta evaluatif. Yakni satu model penelitian yang dimaksud membuat analisis terhadap gambaran (deskriptif) mengenai data-data informasi, kejadian-kejadian secara sistematis, faktual dan akurat.

Dalam perspektif Bogdan dan Taylor (1975:5) pendekatan kualitatif merupakan prosedur peneltian yang menghasilkan data deskriptif berupa kata-kata tertulis atau lisan dari orang-orang dan perilaku yang dapat diamati (dalam Moelong 2000: 3).Sumber data utama berasal dari wawancara dengan Pemerintah Provinsi Jawa Tengah dan DPRD. Sumber data sekunder merupakan dokumen-dokumen yang relevan dengan penelitian ini.

\section{B. PEMBAHASAN}

Infrastruktur adalah mengacu pada sistem fisik yang menyediakan transportasi, air, bangunan, dan fasilitas publik lain yang diperlukan untuk memenuhi kebutuhan dasar manusia secara ekonomi dan sosial. Grigg mengelompokkan infrasruktur dalam enam kategori yakni: 
1) Kelompok jalan (jalan, jalan raya, jembatan)

2) Kelompok pelayanan transportasi (transit, jalan rel, pelabuhan, bandar udara)

3) Kelompok air (air bersih, air kotor, semua sistem air, termasuk jalan air)

4) Kelompok manajemen limbah (sistem manajemen limbah padat)

5) Kelompok bangunan dan fasilitas olahraga luar

6) Kelompok produksi dan distribusi energi (listrik dan gas).

Pembangunan infrastruktur oleh Pemerintah Daerah tidak bisa dilepaskan dari kewenangan pemerintah daerah dalam urusan infrastruktur dalam sistem desentralisasi saat ini. Tujuan negara dalam menerapkan kebijakan desentaralisasi dilihat Smith (dalam Nurcholis, 2007 : 26) berdasarkan beberapa tujuan. Pertama, desentralisasi diterapkan dalam upaya untuk pendidikan politik. Kedua, untuk latihan kepemimpinan politik. Ketiga, untuk memelihara stabilitas politik. Keempat, untuk mencegah konsentrasi kekuasaan di pusat. Kelima, untuk memperkuat akuntabilitas publik Keenam, untuk meningkatkan kepekaan elit terhadap kebutuhan masyarakat. Disamping itu Shabir Chema dan Rondinelli (dalam Syaukani, 2005: 25) menyampaikan paling tidak ada empat belas alasan yang merupakan rasionalitas dari desentralisasi yang salah satunya adalah Desentralisasi dapat mengantarkan kepada adiminstrasi pemerintahan yang mudah disesuaikan, inovatif, dan kreatif. Pemerintah daerah dapat memiliki peluang untuk menguji inovasi, serta bereksperimen dengan kebijaksanaan yang baru di daerah-daerah tertentu tanpa harus menjustifikasinya kepada seluruh wilayah negara. Kalau mereka berhasil maka dapat dicontoh oleh daerah yang lain.

Dalam kepustakaan Amerika Harold F. Alderfer (1964:176) memandang prinsip alokasi kekuasaan Pemerintah pusat ke bawah dalam:

1. Deconcentration yang semata mata menyusun unit administrasi (field stations). Tidak ada kebijakan yang dibuat di tingkat lokal serta tidak ada keputusan fundamental yang diambil.

2. Decentralization, unit-unit lokal ditetapkan dengan kekuasaan tertentu atas bidang tugas tertentu. Mereka dapat menjalankan penilaian, inisiatif, dan pemerintahannya sendiri.

Sementara dalam kepustakaan Inggris Conveyers (1964:176), dibedakan atas:

1. Devolution yang menunjuk pada kewenangan politik yang ditetapkan secara legal dan dipilih secara lokal.

2. Deconcentration yang menunjuk pada kewenangan administratif yang diberikan pada perwakilan badan-badan pemrintah pusat.

Pendapat ahli lainnya yakni Rondinelli melihat desentralisasisebagai penyerahan perencanaan, pembuatan keputusan, atau kewenangan administrasi dari pemerintah pusat kepada organisasi wilayah, pemerintah darah. Desentralisasi dibedakan dalam beberapa jenis yakni:

1. Deconcentration yaitu penyerahan sejumlah kewenangan atau tanggung jawab administrasi kepada tingkat lebih rendah.

2. Delegation yaitu perpindahan tanggung jawab fungsi tertentu kepada organisasi tertentu diluar struktur birokrasi reguler dan hanya dikontrol oleh pemrintah pusat secara tidak langsung.

3. Devolution yaitu pembentukan dan penguatan unit-unit pemerintahan subnasional dengan aktivitas yang secara substansial berada di luar kontrol pemerintah pusat. 
4. Privatization yaitu memberikan semua tanggung jawab atas fungsi-fungsi kepada organisasi nonpemerintah atau perusahaan swasta yang independen dari pemerintah.

Konsep dan model desentralisasi tersebut kemudian akan membawa pada hubungan keuangan antara pemerintah pusat dan pemerintah daerah. Hubungan keuangan pusat dan daerah dapat dipandang dari lima teori yakni:

\section{Fiscal Equalization Theory}

Hubungan keuangan pusat dan daerah dapat menciptakan keseimbangan dalam pelaksanaan nation building dan state building antar daerah dalam penyelenggaraan negara.Pemerintah Pusat berfungsi:

a. Alokasi: mengalokasikan dana yang tersedia secara merata kepada Pemerintah Pusat dan Pemerintah Daerah dengan Peraturan Perundangan dan memperhatikan perbedaan antara daerah.

b. Distribusi: pembagian sumber daya ekonomi dan pendukungnya.

c. Stabilisasi: menciptakan stabilitas ekonomi nasional.

2. Financial Autonomy Theory

Diperlukan otonomi luas dalam penyelenggaraan Pemerintah Daerah dengan maksud agar daerah mampu dan dapat mengatur dan mengurus rumah tangga sendiri dengan penuh tanggung jawab.Daerah diberi sumber keuangan yang cukup, disamping itu Pemerintah Pusat juga memberikan bantuan secara khusus kepada daerah miskin. Hal tersebut berfungsi mengatur bagi pemerintah dan sekaligus menumbuhkan legitimasi kekuasaan.

3. Overall Fiscal Equalization Theory

Pemerintah memberi sumbangan secara merata kepada daerah dengan memperhitungkan tidak saja Financial Cost, tetapi juga Social Cost sebagai pengeluaran Pemerintah Daerah. Daerah yang social cost-nya tinggi akan memperoleh sumbangan yang lebih tinggi (banjir, gempa, wabah penyakit).

4. Revenue Sharing Theory

Antara keuangan Pemerintah Pusat dan Pemerintah Daerah harus terpisah. Jadi pembagian sumber pendapatan antara pemerintah pusat dan Pemerintah Daerah dipisah secara tegas dan masing-masing mempunyai kebebesan secara penuh dalam penggunaannya.

5. Central Grants Theory

Pemerintah pusat perlu memberikan sumbangan kepada daerah dari berbagai sumber keuangan dengan alasan:

a. Untuk menciptakan keseimbangan secara vertikal (antara Pemerintah PusatPemerintah Daerah).

b. Mempromosikan agar tercipta keseimbangan antara daerah untuk memperkecil disparitas antara daerah.

c. Merangsang daerah miskin agar dapat berkembang.

Teori-teori tersebut di atas kemudian diimplementasikan dalam berbagai bentuk seperti misalnya konsep dana transfer atau dana perimbangan yang diberikan oleh Pemerintah Pusat kepada pemerintah daerah di Indonesia. Dana Perimbangan merupakan dana yang bersumber dari pendapatan APBD yang dialokasikan kepada daerah untuk mendanai kebutuhan daerah dalam rangka pelaksanaan desentralisasi. 
Pembangunan infrastrukur oleh pemerintah daerah tidak dapat dilepaskan dari alokasi anggaran infrastruktur melalui APBD. Dalam pengelolaan keuangan daerah, APBD memiliki makna penting yakni:

Pertama, otoriasi. Anggaran daerah menjadi dasar untuk melaksanakan pendapatan dan belanja pada tahun anggaran bersangkutan.

Kedua, perencanaan. APBD menjadi pedoman bagi manajemen dalam merencanakan kegiatan pada tahun yang bersangkutan.

Ketiga, pengawasan. APBD menjadi pedoman untuk menilai apakah kegiatan penyelenggaraan pemerintah daerah sudah sesuai denga ketentuan yang telah ditetapkan.

Keempat, alokasi. Anggaran daerah harus dapat diarahkan untuk menciptakan lapangan kerja/mengurangi pengangguran dan pemborosan sumber daya serta meningkatkan efisiensi dan efektifitas perekonomian.

Kelima, distribusi. Kebijakan anggaran daerah harus memerhatikan rasa keadilan dan kepatuhan.

Keenam, stabilisasi. APBD menjadi alat ukur untuk memelihara dan mengupayakan keseimbangan fundamental perekonomian daerah.

Dengan demikian alokasi anggaran yang besar diharapkan akan mampu meningkatkan kualitas infrastruktur di daerah. Alokasi anggaran infrastruktur juga menjadi cermin perencanaan pembangunan infrasrtuktur pemerintah daerah. Jika alokasi anggaran sudah ditingkatkan, maka bagaimana kemudian implementasi dari program infrastuktur menjadi hal yang menarik. Apakah peningkatan alokasi tersebut mampu meningkatkan kualitas infrastruktur di daerah.

Implementasi kebijakan adalah tahap pembuatan kebijakan antara pembentukan kebijakan dan konsekuensi-konsekuensi kebijakan bagi masyarakat yang dipengaruhinya. Jika suatu kebijakan tidak tepat atau tidak dapat mengurangi masalah yang merupakan sasaran dari kebijakan, maka kebijakan itu mungkin akan mengalami kegagalan jika kebijakan tersebut kurang diimplementasikan dengan baik oleh para pelasana kebijakan.

Van Meter dan Van Horn memandang bahwa pertama, impelementasi kebijakan akan dipengaruhi oleh sejauh mana kebijakan menyimpang dari kebijakan-kebijakan sebelumnya.Kedua, proses implementasi akan dipengaruhi oleh jumlah perubahan organisasi yang diperlukan.

George C Edward III memandang bahwa keberhasilan dalam implementasi kebijakan sangat dipengaruhi oleh empat faktor yang meliputi komunikasi, sumbersumber, kecenderungan-kecenderungan dan struktur birokrasi (dalam Winarno,2002: 126-153). Terdapat tiga hal penting dalam proses komunikasi kebijakan yakni tranmisi, konsistensi, dan kejelasan. Sumber-sumber merupakan faktor penting dalam implementasi kebijakan. Sumber-sumber yang penting meliputi: staf yang memadahi, wewenang, dan fasilitas-fasilitas. Kecenderungan dari para pelaksana kebijakan merupakan faktor ketiga yang memiliki konsekuensi penting bagi implementasi kebijakan yang efektif. Jika para pelaksana bersikap baik terhadap suatu kebijakan, dan hal ini berarti adanya dukungan, kemungkinan besar mereka melaksanakan kebijakan sebagaimana yang diinginkan oleh pembuat keputusan.

Faktor keempat adalah struktur birokrasi. Edwards memandang ada dua hal yang sangat mempengaruhi struktur birokrasi sebagai penentu keberhasilan implementasi kebijakan. Pertama yakni prosedur-prosedur kerja ukuran dasar atau sebagai standard operating procedures. Kedua, fragmentasi dimana struktur organisasi 
birokrasi yang tersebar disamping adanya tekanan-tekanan dari luar seperti lembaga legislatif, kelompok kepentingan.

Tahun infrastruktur di Jawa Tengah dimaknai sebagai tahun dengan fokus pembangunan pada infrastruktur khususnya jalan raya. Fokus tersebut diarahkan pada peningkatan alokasi anggaran infrastruktur yang berasal dari APBD Provinsi Jawa Tengah. Sedangkan untuk program dan kegiatan berfokus pada program peningkatan jalan dan jembatan, program rehabilitas jalan dan jembatan, dan program peningkatan sarana dan prasarana kebinamargaan.

Kebijakan tersebut didasarkan pada kondisi jalan di Provinsi Jawa Tengah dan tuntutan masyarakat yang tercermin dalam kebutuhan masyarakat yang diserap oleh gubernur pada saat proses kampanye pemilihan gubernur. Kondisi pada tahun 2013 menunjukkan bahwa 86,7 persen dalam kondisi baik atau 13,3 persen dalam kondisi rusak. Namun demikian untuk ruas jalan kabupaten/kota yang strategis masih banyak jalan dalam kondisi rusak. Dengan kondisi tersebut maka kemudian gubernur mengambil kebijakan tahun infrastruktur yang dimulai sejak tahun 2014 .

Hasil dari tahun infrastuktur tersebut adalah kondisi jalan di Jawa Tengah yang semakin baik. Pada tahun 2014 persentse panjang jalan dengan kondisi baik mencapai 86,92 persen dan pada tahun 2015 mencapai 88,27 persen. Persentase panjang jalan dengan lebar lebih dari 6 meter juga mengalami peningkatan dari 50,44 persen pada tahun 2013 menjadi 55,24 persen pada tahun 2014 dan menjadi 66,46 persen pada tahun 2015 sebagaimana dalam tabel 1.

\section{Tabel 1}

Indikator, Target dan Realisasi Program Infrastruktur Jalan

\begin{tabular}{|l|c|c|c|c|c|}
\hline \multicolumn{1}{|c|}{ Indikator } & Capaian & \multicolumn{2}{c|}{ Tahun 2014 } & \multicolumn{2}{c|}{ Tahun 2015 } \\
\cline { 3 - 6 } & $\mathbf{2 0 1 3}$ & Target & Realisasi & Target & Realisasi \\
\hline $\begin{array}{l}\text { Persentase jalan dalam } \\
\text { kondisi baik }\end{array}$ & 86,70 & 86,92 & 86,92 & 87,56 & 88,27 \\
\hline $\begin{array}{l}\text { Persentase panjang jalan } \\
\text { dengan lebar > 6 m }\end{array}$ & 50,44 & 54,14 & 55,24 & 59 & 66,46 \\
\hline $\begin{array}{l}\text { Persentase panjang jalan } \\
\text { sebagai jalan kolektor }\end{array}$ & 67,62 & 69,60 & 70,69 & 72,20 & 74,80 \\
\hline
\end{tabular}

Sumber data Dinas Bina Marga Jawa Tengah

Demikian halnya dengan persentase panjang jalan kolektor yang meningkat dari $67,62 \%$ pada tahun 2013 menjadi $70,69 \%$ pada tahun 2014 dan menjadi $74,80 \%$ pada tahun 2015. Dengan data sebagaimana dalam tabel 1 tidak saja target pembangunan yang tercapai namun realisasi dari pembangunan infrasrtuktur jalan sangat meningkat.

Kebijakan tahun infrastruktur bertumpu pada peningkatan alokasi anggaran pembangunan dan rehabilitas jalan dari APBD Jawa Tengah. Peningkatan alokasi anggaran untuk program tersebut dimulai sejak tahun 2014 perubahan, mengingat pada anggaran tahun 2014 murni sudah ditetapkan sebelum gubernur dilantik. Pada tahun 2014 realisasi mencapai Rp 998,6 milliar atau meningkat 92 milliar dari target dalam RPJMD. Anggaran tersebut semakin besar pada tahun 2015 yang mencapai Rp 1,88 trilyun dan pada tahun 2016 mencapai Rp 2,4 trilyun. Alokasi anggaran tahun infrastruktur senantiasa lebih tinggi dari target belanja dalam RPJMD. Kondisi tersebut disebabkan pada saat penetapan RPJMD belum terdapat rencana kebijakan tahun infrastruktur sehingga proyeksi belanja untuk program tersebut tidak nampak peningkatan yang begitu besar sebagaimana dalam Tabel 2.

Tabel 2

Alokasi Anggaran Program Infrastruktur Jalan Dari APBD Jawa Tengah 


\begin{tabular}{|l|r|r|}
\hline Tahun & Realisasi dan Prediksi & \multicolumn{1}{c|}{ Target RPJMD } \\
\hline 2014 & 998.683 .739 .000 & 906.489 .821 .000 \\
\hline 2015 & 1.888 .824 .125 .000 & 1.239 .458 .419 .000 \\
\hline 2016 & 2.429 .980 .450 .000 & 1.617 .491 .026 .000 \\
\hline
\end{tabular}

Sumber data Dinas Bina Marga Jawa Tengah

Peningkatan alokasi anggaran untuk program pembangunan dan rehabilitasi jalan inilah yang sangat menentukan keberhasilan tahun infrastruktur. Peningkatan alokasi anggaran tersebut tidak saja berangkat dari usulan gubernur namun juga adanya komitmen dari DPRD Jawa Tengah yang memiliki pandangan yang sama terhadap pembangunan infrastruktur di Jawa Tengah melalui peningkatan APBD. Dengan komitmen bersama itulah proses penganggaran pembangunan infrastruktur tidak mengalami kendala.

Salah satu dampak dari peningkatan alokasi anggaran infrasrtuktur adalah pengurangan jumlah belanja pada program atau alokasi lainnya. Seperti misalnya pengurangan pada belanja hibah yang secara kebetulan juga mengalami hambatan seiring diberlakukannya Undang-Undang No 23 Tahun 2014 tentang Pemerintahan Daerah yang mengharuskan syarat penerima hibah harus berbadan hukum.

Keberhasilan tahun infrastruktur juga ditentukan oleh kemampuan pemerintah daerah dalam hal ini Dinas Bina Marga dalam melaksanakan kegiatan yang telah direncanakan. Pada tahun 2014 untuk program peningkatan jalan dan jembatan terdapat tujuh kegiatan dengan realisasi anggaran sebesar 97,10 persen. Sedangkan untuk program rehabilitasi jalan dan jembatan terdapat 40 kegiatan dengan realisasi mencapai 98,15 persen. Kemampuan dalam merealisasikan inilah yang kemudian semakin meningkatkan alokasi anggaran pada tahun berikutnya.

\section{PENUTUP}

Tahun infrastruktur merupakan kebijakan peningkatan kualitas infrastruktur khususnya jalan di Provinsi Jawa Tengah melalui peningkatan alokasi anggaran APBD untuk program pembangunan jalan dan rehabilitasi jalan. Kebijakan tersebut berawal dari program gubernur yang didukung oleh komitmen DPRD dalam proses penganggaran. Peningkatan alokasi anggaran untuk program rehabilitasi dan pembangunan jalan telah berhasil meningkatkan kondisi jalan di Provinsi Jawa Tengah. Kemampuan pemerintah daerah dalam hal ini adalah Dinas Bina Marga dalam melaksanakan seluruh kegiatan terkait menjadi pemacu peningkatan alokasi anggaran pada tahun selanjutnya. Salah satu dampak dari kebijakan tersebut adalah berkurangnya sejumlah belanja daerah seperti dana hibah untuk sejumlah alokasi atau jenis belanja hibah.

\section{DAFTAR REFERENSI}

Badjuri, A \& Yuwono. Y. Kebijakan Publik: Konsep dan Strategi. Semarang:JIP UNDIP.2002.

Huda, Ni'matul. Hukum Pemerintahan Daerah. Nusamedia. Bandung.2009

Lexi J Moelong, Metodologi Penelitian Kualitatif. Bandung, Rosdakarya, 2002.

Nugroho, Rian.Public Policy. Elex Media Komputindo.Jakarta.2009

Nurcholis, Hanif, Teori dan Praktik Pemerintahan Dan Otonomi Daerah. Jakarta, Grasindo, 2007.

Patton, M Quinn, Metode Evaluasi Kualitatif. Yogyakarta. Pustaka Pelajar.2006.

Sinambela, Mahadi \& Azhari S, Dilema Otonomi daerah \& Masa Depan Nasionalisme Indonesia. Yogyakarta, Balairung \& Co, 2003. 
Syaukani dkk, Otonomi Daerah Dalam Negara Kesatuan. Yogyakarta, Pustaka Pelajar, 2005.

Tangkilisan, Hessel. Evaluasi Kebijakan Publik. Yogyakarta, Balairung.2003

Winarno, Budi. Teori dan Proses Kebijakan Publik.MedPress.Yogyakarta.2002 